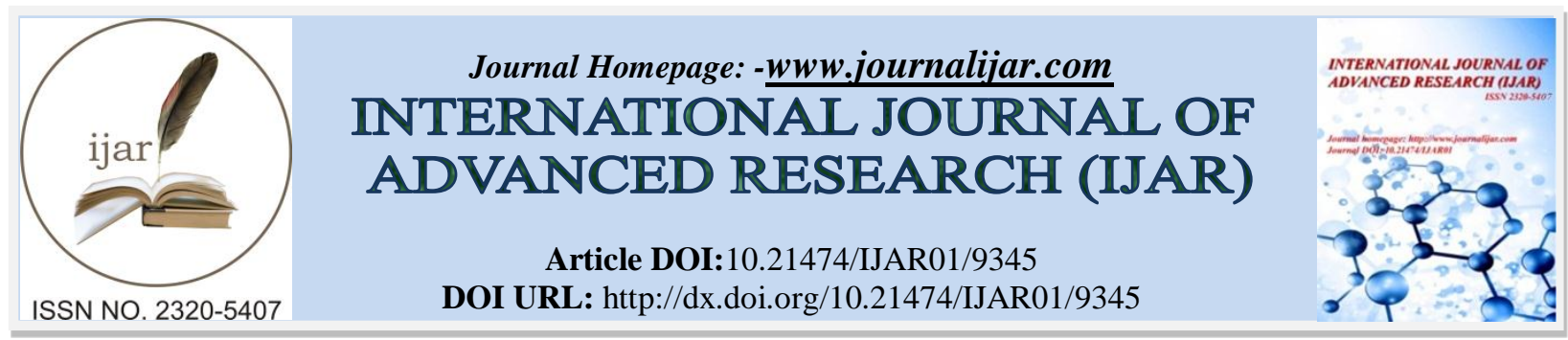

RESEARCH ARTICLE

\title{
PHYTOCHEMICAL SCREENING, PROXIMATE COMPOSITION AND HEAVY METALS OF CAMELLIA SINENSIS LEAVES.
}

\section{Mohammad Majedul Haque ${ }^{1}$, Md. Rashed Hasan1, Shakila Akter², Md. Khabir Uddin Sarker ${ }^{1}$, Shamima Akther Eti ${ }^{1}$ and ${ }^{*}$ Shahin Sultana"}

1. Fibre \& Polymer Research Division, BCSIR Laboratories Dhaka, Bangladesh Council of Scientific and Industrial Research, Dhanmondi, Dhaka-1205, Bangladesh.

2. Institute of National Analytical Research and Service (INARS), Bangladesh Council of Scientific and Industrial Research, Dhanmondi, Dhaka-1205, Bangladesh.

\section{Manuscript Info}

Manuscript History

Received: 05 May 2019

Final Accepted: 07 June 2019

Published: July 2019

\section{Key words:-}

Camellia sinensis Linn, leaves, phytochemicals, proximate compositions, heavy metals, spectrophotometry.

\section{Abstract}

Phytochemical screening, proximate compositions and some heavy metals were assessed on the leaves of Camellia sinensis Linn. Phytochemical screening indicated presence of alkaloids, flavonoids, carbohydrates, tannins, terpenoids, reducing sugars, cardiac glycosides, steroids and saponins. Proximate compositions analysis showed that the percentage of moisture, ash, crude protein, crude fat and crude fibre contents were $9.46 \% \pm 0.31,7.30 \% \pm 0.40,13.65 \% \pm 0.69$, $2.72 \% \pm 0.12$ and $7.69 \% \pm 0.26$ respectively. Spectrophotometric analysis showed that the percentage of heavy metals like $\mathrm{Pb}, \mathrm{As}, \mathrm{Cd}$ and $\mathrm{Hg}$ content were found $0.56 \pm 0.05$, <DL (bellow detection limit), $0.01 \pm 0.001$, and $0.04 \pm 0.007 \mathrm{mg} / \mathrm{kg}$ respectively. The results demonstrated that, the presence of secondary metabolites and moderate amount of proximate compositions and very low concentrations of toxic metals in the leaves of Camellia sinensis are good indication that if it will be subjected to intensive research, bioactive compounds may be isolated and also this study can be used to standardize different medicinal plants. This study therefore suggests that this plant may be useful as nutraceuticals and pharmaceutical agents.

Copy Right, IJAR, 2019,. All rights reserved.

\section{Introduction:-}

Plants are the natural sources of many secondary metabolites (bioactive compounds) possessing important bioactivities. These bioactive components are chemical constituents and have been traditionally used as drugs (Chin et al., 2006). These drugs exhibit several advantages like cost effective, broad spectrum activity, preventive and curative actions, and show fewer side effects (Chin et al., 2006; Pcerangeli et al., 2009; Sermakkani et al., 2012). The medicinal and nutritional values both are important to promote health and safe from illness (Moeller et al., 2000). In any plant species of interest, it is essential to discover its chemical constituents so as to obtain new biomedical sources for the remedy of diseases. The plant Camellia sinensis belongs to the family Theaceae. Leaves, buds and shoots of this plant are used to produce the most widely and popularly used beverage tea. Tea is the most favorite non-alcoholic caffeine-containing beverages after water in all over the world. About 2.5 million tons of tea leaves are produced each year throughout the world (Sharma et al., 2014).Camellia sinensis plant grown best in certain tropical and subtropical regions (Gupta et al.,2014). Falk people use it as a medicine for headache, digestion 
and immune defense (Krishna, et al., 2014). The present study was designed to evaluate the phytochemical constituents, proximate compositions and the concentration of selected heavy metals in the leaves of the mentioned plant. The preliminary study revealed interesting findings which will draw attention to the need for further investigation of the active ingredients identified in the reported species.

\section{Materials and methods:-}

\section{Collection and Identification of Sample}

Freshleaves of Camellia sinensis Linn was collected from Moulvibazar district, Bangladesh and identified (specimen \# DACB 45681) by Bangladesh National Herbarium (BNH), Dhaka. Collected samples were shed dried in absence of sunlight. It was than powdered using a grinding machine. The powdered samples were kept in a dry, air tight container at room temperature prior to analysis.

\section{Qualitative analysis of phytochemicals}

The powdered sample was subjected to qualitative phytchemical analysis and performed using standard procedures described in Sofowara (1993), Trease and Evans (1989) and Harborne (1973).

\section{Test for flavonoids}

Two test methods were used to identify the presence of flavonoids.

First method: Dilute ammonia $(5 \mathrm{ml})$ was added into a test tube containing a portion of aqueous extract of powdered sample. A yellow coloration appeared in the test tube, which disappeared after adding of concentrated sulfuric acid (1 $\mathrm{ml})$, indicates the presence of flavonoids.

Second method: A portion of powdered sample was heated with ethyl acetate $(10 \mathrm{ml})$ over a steam bath for 3 min. The mixture was than filtered; the filtrate $(4 \mathrm{ml})$ was taken in a test tube and shaken with dilute ammonia solution (1 $\mathrm{ml})$. A yellow coloration indicates the presence of flavonoids.

\section{Test of alkaloids}

Powdered sample was extracted by warming with dilute hydrochloric acid and filtered. Two test methods were applied to identify the presence of alkaloids.

First method: Filtrate was treated with drops of Mayer's reagent. Formation of yellowish white cream precipitate indicates the presence of alkaloids.

Second method: Filtrate was treated with drops of Wagner's reagent. Formation of a reddish brown precipitate indicates the presence of alkaloids.

\section{Test for tannins}

Dried powdered sample $(0.5 \mathrm{~g})$ was taken in a test tube containing water $(10 \mathrm{ml})$, boiled and then filtered. A few drops of $0.1 \%$ ferric chloride was added and observed for brownish green or a blue-black coloration.

4. Test for terpenoids (Salkowski test)

About $0.5 \mathrm{~g}$ of the dried powdered sample was extracted and evaporated to dryness. Then chloroform ( $2 \mathrm{ml})$ and concentrated sulfuric acid $(3 \mathrm{ml})$ was carefully added. A reddish brown coloration of the interface indicated the presence of terpenoids.

5. Test for saponin (Foam test)

Aqueous extract of $0.5 \mathrm{~g}$ sample was shaken vigorously with water $(20 \mathrm{ml})$. Produced foam was persisted for more than ten minutes indicated the presence of saponins.

6. Test for carbohydrate

Freshly prepared Molisch's reagent ( 2 drops) was added into the aqueous extract ( $2 \mathrm{ml})$ of sample in a test tube and shaken well. Then conc. $\mathrm{H}_{2} \mathrm{SO}_{4}(2 \mathrm{ml})$ was carefully added on the sides of the test tube. A red, reddish violet or brown ring appeared at the junction of two layers immediately, indicated the presence of carbohydrates.

7. Test for Reducing Sugar (Fehling's test)

Aqueous extract $(2 \mathrm{ml})$ of sample were taken with equal volume of Fehling's solutions (A and B) in a test tube, and shaken vigorously. Formation of a red, brick-red precipitate indicated the presence of reducing sugar.

8. Test for steroids (Liebermann-burchard's test)

Petroleum ether extract of powdered sample $(0.5 \mathrm{~g})$ was dissolved in chloroform $(2 \mathrm{ml})$. Then acetic anhydride $(2$ $\mathrm{ml}$ ) and conc. sulfuric acid $(1 \mathrm{ml})$ was added. Formation of a greenish color, which turns blue on standing, indicates the presence of steroids.

9. Test for anthraquinones

Powdered sample $(0.5 \mathrm{~g})$ was taken in a dry test tube and chloroform $(5 \mathrm{ml})$ was added and shaken for $5 \mathrm{~min}$; then filtered and the filtrate mixed with equal volume of $10 \%$ of ammonia solution. A pink, violet or red color in the aqueous layer indicates the presence of anthraquinones.

10. Test for cardiac glycosides (Keller-Killiani test) 
Aqueous extract of $0.5 \mathrm{~g}$ sample was diluted with $5 \mathrm{ml}$ water. To this, glacial acetic acid $(2 \mathrm{ml})$ containing 1 drop of ferric chloride solution was added. This was then under layered with concentrated sulfuric acid $(1 \mathrm{ml})$. A brown ring obtained at the interface of the two layers indicated the presence of a deoxysugar characteristic of cardioids. A violet ring may appear below the brown ring, while in the acetic acid layer (upper layer) a greenish ring may form just above the brown ring and gradually spread throughout this layer. This test is characteristic of deoxysugars of cardiac glycosides.

\section{Analysis of proximate compositions}

The powdered sample was subjected to proximate analysis. The moisture content, ash, crude fat and crude fibre contents were determined using the standard methods of the Association of Official Analytical Chemists (AOAC, 1990) and crude protein (\% total nitrogen $\times 6.25)$ was determined by the Kjeldahl method (Pearson, 1976). Total carbohydrate was determined by the method of James (1995).

\section{Heavy metal analysis}

Heavy metals were estimated by using the official method of the Association of official Analytical Chemists (AOAC, 1990), upon ash drying of sample with a porcelain crucible in a muffle furnace at $570^{\circ} \mathrm{C}$ for 8 hours. Then dilute $\mathrm{HNO}_{3}(10 \mathrm{ml})$ were added to the ash, and then volume completed to $50 \mathrm{ml}$ with distilled water. The quantification was carried out using an AAS spectrophotometer (model: novAA400PF, Analytic Jena AG, Germany). External standards were used for determination of individual metal. Stock standard solutions of 1000 ppm for individual metal were collected from Sigma-Aldrich. Working standards were prepared by necessary dilutions of stock standard solutions. Calibration curves were prepared by instrument software based on working standards. Concentrations of unknown sample solutions were measured from their individual calibration curves.

\section{Results and discussions:-}

\section{Phytochemical screening}

The results of the phytochemical screening of Camellia sinensis leaves showed the presence of various secondary metabolites such as alkaloids, flavonoids, carbohydrates, tannins, terpenoids, reducing sugars, cardiac glycosides, steroids and saponins while anthraquinone was absent (Table 1).

Table 1:- Phytochemicals present in the leaves of Camellia sinensis

\begin{tabular}{|l|l|l|}
\hline Serial no. & Phytochemical constituents & Test results \\
\hline 1 & Alkaloids & Positive \\
\hline 2 & Flavonoids & Positive \\
\hline 3 & Carbohydrates & Positive \\
\hline 4 & Tannins & Positive \\
\hline 5 & Terpenoids & Positive \\
\hline 6 & Reducing sugars & Positive \\
\hline 7 & Cardiac glycosides & Positive \\
\hline 8 & Steroids & Positive \\
\hline 9 & Anthraquinones & Negative \\
\hline 10 & Saponins & Positive \\
\hline
\end{tabular}

Flavonoids are most common and widely distributed group of polyphenolic substances present in plants (Omoregie et al., 2014). They are potent water soluble antioxidants that function in reducing high blood pressure (Dhawan and Jain, 2005), scavenging free radicals, inhibition of peroxidation and chelating transition metals (Flora, 2009; Oseni and Okoye, 2013). It has been reported that flavonoids have strong anti-inflammatory and anticancer activities (Houghton et al., 1999; Ugwu et al., 2013). Alkaloids are one of the most efficient therapeutically significant phytochemicals in plants. The presence of alkaloids suggests the sample have analgesic, anti- inflammatory and antibacterial properties (Gupta, 1994; Dhale and Mogle, 2011).Tannins containing plant extracts are used as astringents, against diarrhoea and dysentery, as diuretics, against stomach and duodenal tumours (De Bruyne et al., 1999; Bajai, 2001).They are also used as anti-bacterial, anti-inflammatory, antiseptic, antioxidant and haemostatic pharmaceuticals (Jeeshna et al., 2011; Dolara et al., 2005). Tannins are known to be useful for the prevention of cancer as well as treatment of inflamed or ulcerated tissues (Okwu and Emineke, 2006; Li et al., 2003; Adegboye et al., 2008). Saponins have the property of precipitating and coagulating red blood cells (Yadav and Agarwala, 2011) and have an expectorant action useful for upper respiratory tract infections (Dougnon et al., 2012). The saponins 
content may also help in the liver functions, concerning the metabolite of cholesterol (Kabir et al., 2005). Cardiac glycosides are important class of naturally occurring drugs whose actions helps in the treatment of congestive heart failure (Yukari et al., 1995). Terpenoids are effective hydrogen donors; hence they have potentials as antioxidants (Igile et al., 2013).

\section{Proximate compositions}

The proximate composition obtained for the leaves of Camellia sinensis are presented in Table 2. The moisture content of the sample was found to contain $(9.46 \pm 0.31 \%)$. The moisture content gives an indication of water soluble vitamins present in the sample (Adinorteyet al., 2012). The ash content was found to contain $(7.30 \pm 0.40 \%)$. The ash content gives an indication to the rich source of inorganic mineral elements that may be present in the sample (Adinorteyet al., 2012). This high ash content suggests that it is a good source of minerals. Camellia sinensis leaves contained high crude protein value of $(13.65 \pm 0.69 \%)$. It can thus be considered a good source of protein. High amount of protein is essential for growth (Tangka, 2003). Some proteins are involved in structural support, while others are involved in bodily movement, or in defense against germs (Bailey, 2008). The crude fiber was found to contain $(7.69 \pm 0.26 \%)$ in the leaves as an indication that it can be a good source of fibre which might aid digestion, help to reduce serum cholesterol level, risk of coronary heart disease, colon and breast cancer and hypertension (Ganong, 2003). The crude fat content was found to contain $(2.72 \pm 0.12 \%)$. The proximate compositions included lipid analysis in addition to the ash, moisture and protein content that provides a general overview of the nutritional value of the plant (Kirk, 1993). This study shows that leaves of Camellia sinensis Linn are rich in nutritional value and that their usage should be strongly recommended for good health.

Table 2:- Proximate compositions of Camellia sinensis leaves

\begin{tabular}{|l|l|l|}
\hline Serial no. & Parameter & Results (\%) \\
\hline 1 & Moisture content & $9.46 \% \pm 0.31$ \\
\hline 2 & Ash content & $7.30 \% \pm 0.40$ \\
\hline 3 & Crude protein & $13.65 \% \pm 0.69$ \\
\hline 4 & Crude fat & $2.72 \% \pm 0.12$ \\
\hline 5 & Crude fibre & $7.69 \% \pm 0.26$ \\
\hline
\end{tabular}

Data are expressed as mean $\pm \mathrm{SD}(\mathrm{n}=3)$

\section{Heavy metals}

A total of four toxic heavy metals like $\mathrm{Pb}, \mathrm{Hg}$, As and $\mathrm{Cd}$ were analyzed and results are summarized in Tables 3. Nowadays, medicinal plants have been regarded as a potential source of heavy metal toxicity to both man and animals (Dwivedi and Dey, 2002). The most common heavy metals implicated in human toxicity include arsenic, lead, cadmium and mercury. World Health Organization (WHO) prescribes limits of heavy metals in raw medicinal plants (WHO, 2007) (Table 3). However, majority of people, use this plant without checking for heavy metal accumulation.

Table 3:- Heavy metals content in the leaves of Camellia sinensis

\begin{tabular}{|l|l|l|l|}
\hline Serial no. & Toxic elements & $\begin{array}{l}\text { Concentrations } \\
(\mathbf{m g} / \mathbf{k g})\end{array}$ & $\begin{array}{l}\text { Maximum recommended level (mg/kg) according } \\
\text { to WHO }(\mathbf{W H O}, \mathbf{2 0 0 7})\end{array}$ \\
\hline 1 & Lead $(\mathrm{Pb})$ & $0.56 \pm 0.05$ & 10 \\
\hline 2 & Mercury $(\mathrm{Hg})$ & $0.04 \pm 0.007$ & 0.5 \\
\hline 3 & Arsenic $(\mathrm{As})$ & $\begin{array}{l}\text { Less than detection } \\
\text { limit }\end{array}$ & 5.0 \\
\hline 4 & Cadmium $(\mathrm{Cd})$ & $0.01 \pm 0.001$ & 0.3 \\
\hline
\end{tabular}

Data are expressed as mean \pm SD $(n=3)$

Lead $(\mathrm{Pb})$ is the most frequently occurring and stable heavy metal in nature. It is highly hazardous for plants, animals and micro-organisms. Continuous application of fertilizers, fuel combustion and sewage sludge are the major reasons leading to escalation in $\mathrm{Pb}$ pollution. It is a serious cumulative body poison. It has been reported that most of the accumulated lead is sequestered in the bones and teeth (Todd, 1996). This causes brittle bones and weakness in the wrists and fingers. Lead that is stored in bones can re-enter the blood stream during periods of increased bone mineral recycling (i.e., pregnancy, lactation, menopause, advancing age, etc.). Levels of lead beyond the permissible limits or long term use of these contaminated plants could lead to toxicity characterized by colic, 
anemia, chronic nephritis, headache, convulsions, brain damage and central nervous system disorders (Klaassen, 2001; Tong et al., 2000). Mobilized lead can get re-deposited in the soft tissues of the body and can cause musculoskeletal, renal, ocular, immunological, neurological, reproductive, and developmental effects (ATSDR, 1999). Arsenic is a toxic non-essential element. It is present as a contaminant in many traditional remedies. Trivalent arsenic is more toxic to mammals than its pentavalent form. Acute arsenic poisoning is associated initially with nausea, vomiting, abdominal pain, severe diarrhea, encephalopathy and peripheral neuropathy. Chronic toxicity results multisystem diseases including carcinogenesis affecting almost all organs (Ratnaike, 2003; Bhattacharya et al., 2014).Cadmium (Cd) is another hazardous heavy metal which is responsible for several cases of poisoning in both plants and humans. Recently, it is gaining more attention due to wide occurrence in water, soil, milk, dietary and herbal medicinal products (Singh et al., 2014). It accumulates in human body, replaces zinc biochemically and causes hypertension, liver and kidney damage. Cadmium poisoning causes a disease called itai-itai characterized by softening of bones, anemia, renal failure and ultimately death (Nordberg, 1999). The main target organ for Cd following chronic oral exposure is the kidney (ATSDR, 1999). Mercury can cause adverse effects on the renal and nervous systems and can cross the placental barrier, with potential toxic effects on the fetus (Risher, 2003). The leaves of Camellia sinensis contained extremely lower concentrations of $\mathrm{Pb}, \mathrm{Hg}$ and $\mathrm{Cd}$ compared to the permissible limit (Tables 3) defined by WHO (2007), whereas arsenic was not detected.

Form the present investigation; it is clear that, the levels of four potentially toxic heavy metals analyzed were found to be quite below the permissible limits in the leaves of Camellia sinensis Linn. The implication of the present findings may be taken into consideration whilst dealing with the medicinal herbs for human or animal consumption. The results suggest that regular and systematic screening of raw medicinal herbs at quantitative basis is necessary to check the levels of the heavy metal pollutants prior to using them for consumption or manufacture of herbal medicinal formulations so that the possible contamination cannot reach up to the finished herbal products.

\section{Conclusions:-}

Continuous increase in environmental pollution is leading to build up pollutants including heavy metals in plant parts which eventually enter the human food chain. Therefore, regular screening of raw material is must to check the levels of pollutants in plant parts and extracts before using them for human consumption. The results from this study showed that the leaves of Camellia sinensis contain several important phytochemicals and phytonutrients. The presence of necessary phytochemicals, good source of proximate compositions and safe level of toxic metals in the leaves of Camellia sinensis Linn suggest and justify that, it is safe for consumption and also usable as herbal raw material.

\section{References:-}

1. Adegboye, M. F., Akinpelu, D. A. and Okoh, A. (2008): The bioactive and phytochemical properties of Garcinia kola (Heckel) seed extract on some pathogens. African Journal of Biotechnology, 7(21):3934-3938.

2. Adinortey, M. B., Sarfo, J. K., Quayson, E. T., Weremfo, A., Adinortey, C. A., Ekloh, W. and Ocran, J. (2012): Phytochemical Screening, Proximate and Mineral Composition of Launaeataraxacifolia Leaves. Research Journal of Medicinal Plant, 6(2): 171-179.

3. Agency for Toxic Substances and Disease Registry (ATSDR)(1999): Toxicological Profile for Cadmium and Nickel, Agency for Toxic Substances and Disease Registry, US Department of Health and Human Services, Public Health Service, 205-93-0606.

4. Agency for Toxic Substances and Disease Registry (ATSDR)(1999): Toxicological Profile for Lead, Agency for Toxic Substances and Disease Registry, US Department of Health and Human Services, Public Health Service, 205-93-0606.

5. AOAC, (1990): Official Method of Analysis $15^{\text {th }}$ Edn., Association of Analytical Chemist. Washington DC, USA.

6. Bailey, R. (2008): The Role of Proteins in the Body, About.com Guide to Biology.

7. Bajai, A. Meyers (2001): "Effect of Natural extract of pineapple on disstibility, performance traits and nitrogen balance of broiler chicks". Australian Journal of Basic and applied Sciences, 5(20):10-30.

8. Bhattacharya, S., Das, S. K. and Haldar PK (2014): Arsenic induced myocardial toxicity in rats: Alleviative effect of Trichosanthesdioica fruit. J. Diet. Suppl.,11: 248-261.

9. Chin, Y. W., Balunas, M. J., Chai, H. B. and Kinghorn, A. D. (2006): Drug discovery from natural sources. AAPS J.,8: E239-53. 
10. De Bruyne, T., Pieters, L., Deelstra, H. and Vlietinck, A. (1999): Condensed vegetables tannins: biodiversity in structure and biological activities. Biochem.System. Ecology, 27: 445-459.

11. Dhale, D. A., and Mogle, U. P. (2011): Phytochemical and Antibacterial Activity of Phyllanthusemblica (L.). Science Research Reporter, 1: 138-142.

12. Dhawan, V. and Jain, S. (2005): Garlic supplementation prevents oxidative DNA damage in essential hypertension. Molecular and Cellular Biochemistry, 275: 85-94.

13. Dolara, P., Luceri, C., De Filippo, C., Femia, A. P., Giovannelli, L., Carderni, G., Cecchini, C., Silvi , S., Orpianesi, C. and Cresci, A. (2005): Red wine polyphenols influence carcinogenesis, intestinal microflora, oxidative damage and gene expression profiles of colonic mucosa in F344 rats. Mutation Res., 591: $237-246$.

14. Dougnon, T.V., Bankole, H.S., Johnson, R.C., Klotoe, J.R.,Dougnon, G., Gbaguidi, F., Assogba, F., Gbenou, J., Sahidou, S., Ategbo, J.M., Rihn, B.H., Loko, F., Boko, M. and Edorh, P.A. (2012): Phytochemical screening, nutritional and toxicological analyses of leaves and fruits of Solanummacrocarpon Linn.(Solanaceae) inCotonou(Benin).Food Nutr. Sci., 3(11): 1595-1603.

15. Dwivedi, S. K. andDey, S. (2002): Medicinal herbs: A potential source of toxic metal exposure for man and animals in India. Arch. Environ. Health, 57(3):229-231.

16. Flora, S.J.S. (2009): Structural, chemical and biological aspects of antioxidants for strategies against metal and metalloid exposure. Oxid.Med.Cell. Longevity, 2(4): 191-206.

17. Ganong, W. F. (2003): Circulating Body Fluids: Review of Medical Physiology. 21 ${ }^{\text {st }}$ Edn., Typo Press, Lebanon.

18. Gupta, D. A., Bhaskar, D. J., Gupta, R. K., Karim, B., Jain, A. and Dalai, D. R. (2014): Green tea: a review on its natural anti- oxidant therapy and cariostatic benefits. Biol.Sci.Pharma. Res., 2(1):008-012.

19. Gupta, S.S. (1994): Prospects and perspective of natural plant products. Indian J. Pharmacol., 26(1): 1-12.

20. Harborne, J. B. (1973): Phytochemical methods, London. (Chapman and Hall, Ltd), pp 49-188.

21. Houghton, P. J., Woldemariam, T. Z., O’Shea, S., Mullen, J. E., Rostron, J., Bantvala, J. E., Walker, E., Thyagarajan, S. P., Soloman, S. and Yeap, F. L. (1999): The anti-HIV activity of an aqueous extract and polyphenoliccompounds ofPhyllanthusamarus. J. Pharm. Pharmacol., 51: 100.

22. Igile, G.O., Iwara, I.A., Mgbaje, B.A., Uboh, F.E. and Ebong, P.E. (2013): Phytochemical, proximate and nutrient composition of VernoniacalvaonaHook (Astereceae): A green -leafy vegetable in Nigeria. J. food Res., 2(6): $1-11$

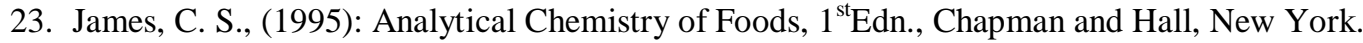

24. Jeeshna, M. V., Paulsamy, S. and Mallikadevi, T. (2011): Phytochemical Constituents and Antimicrobial Studies of the Exotic Plant Species, Croton bonplandianumBaill. J. Life Sci., 3: 23-27.

25. Kabir, O. A., Olukayode, O., Chidi, E. O., Christopher, C. I., and Fasure, K. A. (2005): Screening of crude extracts of six medicinal plants used in South west Nigerian unorthodox medicine for anti-methicillin resistant Staphylococcus aureus activity. BMC Complementary and Alternative Medicine, 5: 6.

26. Kirk, R. S. (1993): Analysis of Food.In: Encyclopedia of Food Science, Food Technology and Nutrition:Macrae, R., Robinson, R. K., Sadler, M. J. ed. (Academic Press, New York), pp 183 - 188.

27. Klaassen, C. D. (2001): Casarett and Doull's toxicology: the basic science of poisons. (New York, USA: McGraw-Hill).

28. Krishna, D. G., Alkindi, J., Alshukili, M., Alhabsi, A. and Devi, C. K. (2014): Int. J. of Inorganic and Bioinorganic Chemistry, vol. 5, no.1, 16-18.

29. Li, H., Wang, Z. and Liu, Y. (2003): Review in the studies on tannins activity of cancer prevention and anticancer. Zhong-Yao-Cai, 26(6):444-448.

30. Moeller, S. M., Jacques, P. F. and Blumberg, J. (2000): The potentia role of dietary xanthophylls in cataract and age-related macular degeneration. Journal of the American College of Nutrition, 19: 522- 527.

31. Nordberg, G. (1999): Excursions of intake above ADI: case study on cadmium. Regul.Toxicol.Pharmacol., 30: S57-S62.

32. Okwu D. E. and Emenike I. N. (2006): Evaluation of the phytonutrients and vitamin contents of Citrus fruits. Int. J. Mol. Med. Adv. Sci. 2:1-6.

33. Omoregie, E. S., Oriakhi, K., Oikeh, E. I.,Okugbo, O. T. and Akpobire, D. (2014): Comparative study of phenolic content and antioxidant activity of leaf extracts of Alstoniaboonei and Eupatorium odoratum. Nig. J. Basic Appl. Sci., 22(3\&4): 91-97.

34. Oseni, O. A. and Okoye, V. I. (2013): Studies of phytochemical and antioxidant properties of the fruit of watermelon (Citrulluslanatus) (Thunb). J. Pharm. Biomedical Sci., 27(27): 508-514.

35. Pcerangeli, G., Vital, G. and Rivera, W. (2009): Antimicrobial activity and cytotoxicity of Chromolaenaodorata (L. F.) king and rabinson and Uncariaperrottetii (A. Rich) Merr extracts. J. Med. Plants Res.,3(7):511-8. 
36. Pearson, D.(1976): The Chemical Analysis of Foods. $7^{\text {th }}$ Edn., Churchill Livingstone, London, ISBN: 0443014116, pp:7-11.

37. Ratnaike, R. N. (2003): Acute and chronic arsenic toxicity. Postgrad. Med. J.,79: 391-396.

38. Risher, J. F., WHO (2003): Elemental mercury and inorganic mercury compounds: human health aspects, 50, World Health Organization, Geneva, Switzerland.

39. Sermakkani, M. andThangapandian, V. (2012): GC-MS analysis of Cassia itallica leaf methanol extract. Asian J. Pharm.Clin. Res., 5(2):90-4.

40. Sharma, M., Nagori, K., Soni, S., Swarnakar, H., Vaishnav, S., Nazir, Md., Khan, N. andPandy, T. (2014): International Journal of Pharmaceutical and Chemical Sciences, 3(1): 110-117.

41. Singh, K. P., Bhattacharya, S. and Sharma, P. (2014): Assessment of heavy metal contents of some Indian medicinal plants. American- Eurasian J. Agric. Environ. Sci.,14: 1125-1129.

42. Sofowara, A. (1993): Medicinal Plants and Traditional Medicine in Africa. $2^{\text {nd }}$ ed, (Spectrum Books Ltd, Ibadan, Nigeria). pp191-289.

43. Tangka, J.K. (2003). Analysis of the thermal energy requirements for the extraction of leaf protein concentrate from some green plants. Biosystems Eng., 86(4): 473-479.

44. Todd,G. C. (1996): Vegetables Grown in Mine Wastes. Environ. Toxicol.and Chem., 19(3): 600-607.

45. Tong, S., von Schirnding, Y. E. andPrapamontol, T. (2000): Environmental lead exposure: a public problem of global dimension. Bull World Health Organ.,78: 1068-1077.

46. Trease, G. E. and Evans, W. C. (1989):Pharmacognsy.11 ${ }^{\text {th }}$ Edn.(BrailliarTiridel Can. Macmillianpublishers).pp45-50.

47. UgwuOkechukwu, P. C, NwodoOkwesili, F. C, Joshua Parker, E., BawaAbubakar, Ossai Emmanuel, C. and Odo Christian, E. (2013): Phytochemical and Acute Toxicity Studies ofMoringaoleifera Ethanol Leaf Extract. International Journal of Life Sciences Biotechnology and Pharma Research, 2(2):66-71.

48. WHO (2007): Guidelines for assessing quality of herbal medicines with reference to contaminants and residues. World Health Organization, Geneva, Switzerland.

49. Yadav, R. N. S. and MuninAgarwala.(2011): Phytochemical analysis of some medicinal plants. Journal of Phytology, 3(12):10-14.

50. Yukari, I., Youichi, F., Ikuko, N. andItsuru, Y. (1995): Quantitative HPLC analysis of cardiac glycosides in Digitalis purpurea leaves. J. Nat. Prod., 58(60):897-901. 